\title{
ФОРМИРОВАНИЕ ТЕОРИИ СРЕДЫ РАЗВИТИЯ ЛИЧНОСТИ В ОТЕЧЕСТВЕННОЙ ПЕДАГОГИЧЕСКОЙ ПСИХОЛОГИИ
}

\author{
В.А. ЯСВИН
}

ГАОУ ВО «Московский городской педагогический университет», Россия, 123022, Москва, Столярный пер., д. 16

\begin{abstract}
Резюме
На основе анализа публикаций выделены этапы средовых исследований личностного развития в российской психологии: педологический - 1920-е - начало 1930-х гг.; культурнодеятельностный - 1930-1960-е гг.; пространственный - 1970-е гг.; личностно-средовой с середины 1990-х гг.; эколого-психологический - с начала XXI в.; эколого-педагогический - формируется в настоящее время. Проведен сравнительный анализ основных методологических подходов, на базе которых проводятся исследования образовательных сред в современной российской педагогической психологии и педагогике: коллекционерского, пространственно-предметного, социально-психологического, средового в воспитании, культурно-исторического и экологического подходов. Обоснована возможность разработки обобщенной теории среды развития личности на основе синтеза ключевых положений данных подходов. Выявлен понятийно-терминологический и структурно-содержательный волюнтаризм в понимании и использовании понятия «образовательная среда», снижающий качество психолого-педагогических исследований. Освоение личностью развивающих возможностей среды рассматривается как основной психологический механизм взаимодействия личности со средой и как содержание психологического проектирования личностно развивающей среды. Сформулировано понятие образовательной среды и разработана ее структурно-содержательная модель, синтезирующие ключевые положения различных научных школ. Образовательная среда понимается как пространственно и/или событийно ограниченная совокупность возможностей для развития личности, возникающих при ее взаимодействии со своим социальным и пространственно-предметным окружением. Предложен комплекс системных параметров дескрипции среды, содержательно интегрирующий различные направления исследований среды развития личности: широта, интенсивность, осознаваемость, обобщенность, эмоциональность, доминантность, когерентность, социальная активность, структурированность, мобильность, безопасность и устойчивость. Формирующееся научное направление «экологическая психология образования» может стать основой для создания экологической (средовой) педагогики, обеспечивающей проектирование личностно развивающих социальных и образовательных сред. Экологическая психология образования создает «психологическую матрицу» (процессы, механизмы, принципы, методы), на которую может быть наложена соответствующая педагогическая калька (технологии, приемы, методики).
\end{abstract}

Ключевые слова: средовые исследования в психологии, среда развития личности, образовательная среда, экологическая психология образования, условия и возможности среды. 


\section{Этапы исследований среды развития личности}

Философия образования традиционно рассматривает среду как один из важнейших факторов развития личности. Все наследие классиков педагогики от Я.А. Коменского, Дж. Локка, Ж.-Ж. Руссо и К.Д. Ушинского до М. Монтессори, А.С. Макаренко и В.А. Сухомлинского, по существу, посвящено описанию их авторских проектов сред, обеспечивающих личностное развитие ребенка.

В начале ХХ в. понятие «среда» включается К.Н. Вентцелем в его педагогическую теорию, рассматривается ряд методологических положений проектирования среды развития ребенка, которые во многом предвосхитили современное понимание взаимодействия личности со средой. Подчеркивался субъективный характер среды («для каждого индивидуума существует своя среда»); была показана взаимообусловленность изменений личности и среды; различалось влияние на формирование нравственности ребенка опосредованной («среда в широком смысле») и непосредственной среды («среда в узком смысле»); выделялись предметная среда (между личностью и природой, «вещественным» миром) и социальная среда (между личностью и другой личностью, обществом).

Исследования механизмов воздействия среды на развитие личности стали популярны в отечественной педологии в 1920-е гг. под влиянием «педагогики среды» и «средоведения», зародившихся в Германии. Изучению «социальноисторической классовой среды» придавалось важнейшее значение в работах П.П. Блонского, А.Б. Залкинда, С.С. Моложавого и др.

Аналитический обзор средовых исследований данного периода представлен в ряде историко-педагогических работ (Лисицкая, 1996; Мануйлов, 1997; и др.). Можно констатировать, что в этот исторический период сформировался «коллекционерский подход», рассматривающий совокупность педагогически значимых условий и факторов среды, который вызывает ассоциацию с «дурной бесконечностью» (нем. die Schlecht-Unendliche), по Г. Гегелю, определяющему таким образом однотипное описание какой-либо действительности, не приводящее к системному результату. В дальнейшем изучение роли среды в развитии ребенка было свернуто практически на полвека из-за обвинений педологов в «фаталистической обусловленности судьбы детей... влиянием... какой-то неизменной среды» ${ }^{1}$.

Характерным примером научно-идеологических дискуссий начала 30 -х гг. является спор А.Н. Леонтьева с Л.С. Выготским о механизмах влияния среды на становление личностиํ․ А.Н. Леонтьев настаивал на том, что влияние среды определяется содержанием деятельности, не соглашаясь с Л.С. Выготским, который ключевым механизмом влияния среды считал переживание.

\footnotetext{
${ }^{1}$ Постановление ЦК ВКП(б) от 4 июля 1936 г. «О педологических извращениях в системе Наркомпросов» // Правда. 5 июля 1936 г.

2 Леонтьев А.Н. О учении о среде в педологических работах Л.С. Выготского (критическое исследование) // Архив Психологического института РАО. Ф. 82. Оп. 3. Ед. хр. 402. (Рукопись обнаружена И.В. Равич-Щербо.)
} 
В дальнейшем С.Л. Рубинштейн подчеркивал, что вместо традиционного дуалистического подхода «среда - личность» необходимо включать саму личность в структуру среды в качестве «активного деятеля». При этом С.Л. Рубинштейн разводит понятия «внешняя среда» и «условия жизни». Условия жизни обеспечивают «единство объективности среды и субъективности человека». Подчеркнем, что среда рассматривается здесь как категория объективная. В то же время, следуя культурно-исторической теории Л.С. Выготского, А.Р. Лурия рассматривал «культурно-историческую среду» не как условие, а как источник психического развития, «формирующий содержание сознательных и бессознательных слоев психики». Психологические механизмы и стратегии освоения субъектом учебной среды изучались П.Я. Гальпериным и Н.Ф. Талызиной на основе теории ориентировочной основы действия, согласно которой образ действия и образ среды действия объединяются в единый структурный элемент, на основе которого происходит управление действием.

Можно констатировать, что в течение нескольких десятилетий в условиях доминирующего в отечественной психологии деятельностного подхода среда развития личности не рассматривалась как самостоятельный предмет исследования, всегда включалась в контекст тех или иных деятельностных теоретических конструктов, часто заменялась понятиями «мир», «внешние условия» и т.П.

Многие, глубоко проработанные положения деятельностного подхода оказали в дальнейшем существенное влияние на характер исследований собственно средовой проблематики, которая возвращается в отечественную педагогическую психологию в 1970-е гг. Начинается изучение влияния пространственной организации школьной среды на поведение учащихся (Давыдов, Переверзев, 1976; Нийт и др., 1985).

Всплеск средовых психолого-педагогических исследований пришелся на 1990-е гг. В этот период начинает активно использоваться понятие «образовательная среда» и формируется ряд методологических подходов к ее изучению, классификация которых предложена В.И. Пановым: эколого-личностный В.А. Ясвина, коммуникативно-ориентированный В.В. Рубцова, антропологопсихологический В.И. Слободчикова и психодидактический В.П. Лебедевой, В.А. Орлова и В.И. Панова (Панов, 2004). Представляется совершенно необходимым дополнить этот перечень средовым подходом в воспитании Ю.С. Мануйлова (Мануйлов, 1997).

Влияние на становление отечественных средовых подходов оказали работы Э. Брунсвика, К. Левина, А. Маслоу, Р. Зоммера, Х. Озмонда, К. Павлика и др. Анализ результатов обзора зарубежных исследований (Смолова, 2015) свидетельствует о том, что современные исследователи образовательной среды опираются, прежде всего, на экологические подходы У. Бронфенбреннера (Bronfenbrenner, 1989) и Дж. Гибсона (Gibson, 1979), а также на методологию социальной психологии и носят явные признаки коллекционерского подхода.

Анализ результатов обзора современных российских исследований образовательных сред (Исаева, 2012) показал, что большинство из них характеризуется 
методологической нечеткостью, продолжают в целом опираться на, очевидно, неконструктивный коллекционерский подход, а также отличаются понятийно-терминологическим волюнтаризмом. Эмпирические исследования средовой проблематики сосредоточены в основном вокруг взаимоотношений и коммуникации членов образовательных сообществ, в меньшей степени посвящены организации школьного пространства и редко затрагивают вопросы системного изучения среды.

Таким образом, можно выделить четыре этапа средовых исследований в отечественной психологии: педологический - 1920-е - начало 1930-х гг. (П.П. Блонский, А.Б. Залкинд, С.С. Моложавый и др.); культурно-деятельностный - 1930-1960-е гг. (Л.С. Выготский, А.Н. Леонтьев, А.Р. Лурия, С.Л. Рубинштейн, П.Я. Гальперин, Н.Ф. Талызина и др.); пространственный - 1970-е гг. (В.В. Давыдов, Х.Й. Лийметс и др.); личностно-средовой - с середины 1990-х гг. (Ю.С. Мануйлов, В.И. Панов, В.В. Рубцов, В.И. Слободчиков, В.А. Ясвин и др.).

\section{Типология методологических подходов в педагогической психологии и педагогике}

В настоящее время средовые исследования образовательной проблематики в отечественной педагогической психологии осуществляются на основе нескольких методологических подходов, сформировавшихся в рамках определенных научных школ.

1. Коллекционерский подход, как уже отмечалось, широко распространен в исследовательской практике и характеризуется акцентом на выявление и дескрипцию многочисленных педагогически значимых условий и факторов различных образовательных сред (от «информационной» до «здоровьеформирующей»). Теоретические модели среды в рамках данного подхода отличаются недостаточной системностью, содержательной полнотой и научной четкостью, вследствие чего эмпирические исследования часто носят эклектичный характер. Образовательная среда определяется нечетко в логике совокупности факторов личностного развития и социализации как «развивающийся континуум» пространственно-временных, социально-культурных, деятельностных, коммуникативных, информационных и других факторов (Артюхина, 2006). Методологические основания коллекционерского подхода можно найти в средоведческих и педологических работах первой трети XX в.

2. Пространственно-предметный подход сосредоточен на проблематике организации пространств в учебных зданиях и предметной среды развития детей. Данный подход основывается на развитии идей М. Монтессори, а также на методологии поведенческой географии. В СССР пространственнопредметный подход разрабатывался эстонской психологической школой Х.Й. Лийметса, был реализован в ряде работ сотрудников научной группы В.В. Давыдова. Под руководством В.А. Петровского была разработана концепция построения предметно-развивающей среды (Петровский и др., 1993). Проводятся исследования обусловленности активности и взаимодействий 
учащихся, их учебной успешности особенностями их пространственного расположения в классе (Савенков, 2006); удовлетворенности учащихся пространственно-предметной средой своей школы, а также ранжирование значимых для школьников параметров среды (Иванова Н.В., 2016), предметно-пространственной среды школы методом семантического дифференциала (Иванова и др., 2018) и т.п.

3. Социально-психологический подход широко применяется как в российских (Рубцов, 2001; Слободчиков, 2000; и др.) , так и в зарубежных исследованиях образовательных сред. Исследовательские задачи успешно решаются на основе методов социальной психологии. Например, изучается, как учителя относятся к школьникам различных национальностей (McKown, Weinstein, 2008); каковы особенности взаимодействия и коммуникации («виды общности») между различными членами образовательных сообществ (Рубцов, 2001) и т.п.

4. Средовой подход в воспитании разрабатывается Ю.С. Мануйловым в рамках его научной школы. Среда развития личности характеризуется, вопервых, через природные, социальные и культурные «ниши», обозначающие ограниченное пространство возможностей, опосредующих развитие ребенка; во-вторых, через «стихии» как движущие силы среды; в-третьих, через «меченых индивидуумов», которые являются потенциальными носителями изменений в среде. Дескрипция «ниш» осуществляется через такие их характеристики, как величина, встроенность, доступность, трофическое однообразие или разнообразие. «Стихии» могут характеризоваться фронтом движения, силой влияния, формой проявления. Оригинальность понятийного аппарата, предложенного Ю.С. Мануйловым, осложняет его «совместимость» с традиционной терминологией других исследователей.

5. Культурно-исторический подход, предвосхищенный педагогическими проектами К.Н. Вентцеля, методологически разработанный Л.С. Выготским, получивший развитие в трудах А.Р. Лурии и их учеников, получивший в итоге всемирное признание, основан на положениях об активности среды, активности педагога и активности самого ребенка в процессе своего развития. Среда, прежде всего социальная, рассматривается как главный фактор воспитания, как совокупность отношений, представляется исключительно пластичным, гибким, идеальным психолого-педагогическим инструментом развития личности. Функция воспитателя предусматривает посредничество между ребенком и его средой, организацию и регулирование этой среды.

6. Экологический подход в изучении среды основан на работах классиков психологической науки (Э. Брунсвик, К. Левин, А. Маслоу), инвайронментальных (экологических) психологов (G. Proshansky, K. Pawlik, J. Gibson и др.), инвайронментальных социологов (O. Duncan, L. Schnore и др.) и педагогических психологов (U. Bronfenbrenner и др.). В России этот подход получил развитие в конце ХХ в. в теоретических и эмпирических исследованиях (Абрамова, 1995; Климов, 2001; Ковалев, 1993; Лебедева и др., 1996; Ясвин, 1997; и др.). Экологический подход характеризуется системностью, развернутым инструментально-методическим арсеналом, широко используется в образовательной практике. 
Можно констатировать, что методологические подходы изучения среды развития личности, отличаясь направленностью и уровнем системности исследований, не носят антагонистического характера по отношению друг к другу. Очевидна их взаимодополняемость, обеспечивающая возможность синтеза их основных положений в контексте формирования обобщенной теории личностно-развивающей среды.

\section{Терминологический анализ средовых исследований}

Доминирующее понятие «образовательная среда» понимается и формулируется по-разному различными авторами. Среда рассматривается как то, среди чего (кого) пребывает субъект, что опосредует его развитие и осредняет («типизирует») личность (Ю.С. Мануйлов); как часть социокультурного пространства, в котором происходит саморазвитие личности (Н.Б. Крылова); как окружающая индивида обстановка и граница (В.И. Слободчиков) и т.п. В любом случае речь идет о среде как о сложной системе, включающей самого человека, который строит те или иные элементы среды и тем самым создает ее для себя. Выделяются различные среды развития личности (Иванов, 2016): окружающая, социальная, социокультурная, образовательная (педагогическая), обучающая (дидактическая), информационная и коммуникационная среда той общности, в которую включен ребенок (семья, референтная группа, класс).

Для обозначения исследуемых сред обычно используется дуальный конструкт, включающий их институциональную принадлежность и функциональную направленность: «здоровьесберегающая среда в детском дошкольном учреждении» (С.С. Иванова); «воспитательная среда образовательного учреждения» (И.А. Колесникова); «сетевая образовательная среда вуза» (Т.Н. Носкова, Т.Б. Павлова); «образовательная среда в дистанционном эвристическом обучении» (А.В. Хуторской) и т.п.

Терминологическая размытость и неопределенность возникает уже на стадии использования понятий «образовательная среда» и «образовательное пространство», которые нередко понимаются как синонимы. В то же время большинство исследователей с этим не согласны, подчеркивая, что среда отличается от пространства тем, что предполагает включенность человека в совокупность условий его существования. В отдельных случаях можно констатировать не просто терминологическую размытость, но и полный понятийно-терминологический волюнтаризм: «Два фундаментальных понятия уклада школьной жизни: “образование” и “культура” - объединены категорией “образовательное пространство”. Интеграция в общее семантическое пространство придает каждому из них дополнительное значение. Пространство, интегрированное с образованием, не равно пространству как таковому. В контексте образования пространство раскрывается в своем культурно-антропологическом измерении» (Корсакова, 2010, с. 45).

Вместе с тем, согласно словарному определению, «пространство» - это форма сосуществования материальных объектов и процессов, объективная 
реальность, форма существования материи (Ожегов, 1986). «Среда» же предполагает процесс взаимодействия с субъектом, создание условий и механизмов развития и саморазвития субъектов, наличие средств для удовлетворения их целей (Иванов, 2011). Следовательно, школу нужно рассматривать в качестве институционального «носителя» определенной образовательной среды, а систему школ - как образовательное пространство (Богданов, Тюмасева, 2003).

В исследованиях различных социальных феноменов школьной среды традиционно используется целый ряд близких по содержанию понятий, таких как «уклад школы» (С.Н. Вачкова, А.А. Остапенко, А.Н. Тубельский, И.Д. Фрумин, Т.П. Хренова и др.); «школьная культура» и «организационная культура школы» (Л.Е. Асадчих, П. Карстанье, Н.Б. Крылова, Е.М. Моргачева, А.В. Мудрик, Ю.Ю. Темрюков, К.М. Ушаков, В.Я. Ясницкая и др.); «организационно-педагогическая культура» (Л.Б. Малыхина); «дух школы» или «этос школы» (Б.М. Бим-Бад, К.Д. Ушинский, Т.В. Цырлина, С.Т. Шацкий и др.); «психологический климат школы» и «эмоционально-психологический климат школы» (И.Б. Авакян, Н.П. Аникеева, А.С. Макаренко и др.). Можно констатировать, что все эти понятия относятся к изучению характеристик социального компонента школьной среды.

В зарубежных средовых исследованиях (J.T. Gatto, H. Giroux, P.W. Jackson, J. Kozol, N. Postman и др.) используется ряд нечетких понятий, таких как «негласное образование» (tacit education), «скрытый учебный план» (hidden curriculum), «дизайн обучения» (design training), «школьная атмосфера» (school atmosphere), «климат в классе» (the climate in the class), «культура школы» (school culture) и т.п.

Таким образом, терминологический анализ средовых исследований позволяет констатировать отсутствие общепринятой терминологии, приводящее в ряде случаев к волюнтаристическому и некорректному использованию понятий на фоне их общей размытости и нечеткости, а также отсутствию их структурированности и иерархической соподчиненности. Очевидно, что выходом из сложившегося положения может служить обобщенная, признаваемая различными исследователями синтетическая модель личностно-развивающей среды и соответствующая данной модели система параметров ее психологопедагогической дескрипции.

\section{Структурно-содержательные модели и параметры среды развития личности}

Структурно-содержательное моделирование среды и выбор параметров ее психологической дескрипции также обусловлены разнообразием методологии средовых подходов, сформировавшихся в отечественной педагогической психологии на рубеже XX в.

В основу первых отечественных исследований данного периода оказалась заложена структурно-содержательная модель «экологического комплекса», включающая «популяцию», «организацию», «пространство» и «технологию» (Duncan, Schnore, 1959). Наиболее популярной стала трехкомпонентная 
структура образовательной среды, в которой исследователи склонны объединять «организацию» и «технологию» в единый средовой компонент: «физическое окружение», «человеческие факторы» и «программа обучения» (Г.А. Ковалев); «качество предметно-пространственной среды развития», «характер взаимодействия между сотрудниками и детьми», «соответствие образовательно-воспитательного процесса современным программам обучения и воспитания» (Н.Н. Авдеева, Г.Б. Степанова); предметно-пространственный, социальный и организационно-технологический компоненты (В.А. Ясвин); пространственно-семантический, коммуникационно-организационный и содержательно-методический компоненты (Ю.Н. Кулюткин, С.В. Тарасов) и т.п.

В «антрополого-психологической» модели В.И. Слободчикова выделяются «насыщенность» (ресурсный потенциал) и «структурированность» (способ организации) среды. «Коммуникативно-ориентированная» модель школьной среды В.В. Рубцова включает «внутреннюю направленность» школы, психологический климат, социально-психологическую структуру коллектива, психологическую организацию передачи знаний, психологические характеристики учащихся и т.д.

К относительно устоявшимся пространственно-предметному («материальному», «физическому» и т.п.), социальному («общественному» и т.п.) и организационно-технологическому («психодидактическому» и т.п.) структурным компонентам среды современные исследователи склонны добавлять новые «расширяющие» и «уточняющие» компоненты: «духовный» (традиции и ценности) компонент (Головлева, 2015); «организационно-управленческий» (компетентность и управленческая культура администрации образовательного учреждения и т.п.) и «субъектный» компоненты (личностные, возрастные, психофизиологические и другие особенности субъектов образовательной среды) (Лактионова, 2013); «синергетический», включающий «условия, способствующие комплексному согласованному во всех своих проявлениях (эмоциональных, когнитивных, коммуникативных, личностных) взаимодействию школьника с образовательной средой, содержащие в себе “сжатый” опыт предыдущих взаимодействий, настоящих и будущих целей взаимодействий, способствующих проявлению законов самоорганизации сложных и открытых систем» (Григорьева, 2010, с. 178) и т.п. Совершенно очевидно, что содержание «духовного» компонента С.М. Головлевой и «субъектного» компонента Е.Б. Лактионовой включено в традиционный социальный компонент среды, содержание «организационно-управленческого» компонента Е.Б. Лактионовой является частью содержания организационно-технологического компонента среды, а «синергетический компонент» М.В. Григорьевой, судя по описанию автора, раскрывает, скорее, качественную, а не структурную характеристику среды.

Школьная среда описывается с учетом ее соответствия санитарно-гигиеническим требованиям, эстетичности, технической оснащенности, персонализированности, безопасности, символической насыщенности, открытости, возможности пространственной трансформации, информационности (Иванова Н.В., 2016) и т.п. 
В зарубежных исследованиях популярно исследование среды на основе идеи Дж. Гибсона о «встроенности» объектов в «экологическом мире» (Гибсон, 1988) и модели среды У. Бронфенбреннера, в рамках которой выделяются: микросистема - межличностные взаимодействия, переживаемые человеком; мезосистема, состоящая из связей между несколькими микросистемами (например, между семьей и школой); экзосистема - связи между микросистемами и мезосистемами (например, опосредованное влияние на ребенка профессиональных взаимодействий его родителей); макросистема переплетение микро-, мезо- и экзосистем в рамках более широкого социального контекста (этническая или религиозная группа, профессиональное сообщество и т.п.), связанного с источниками и возможностями развития личности (Bronfenbrenner, 1979).

Структура среды раскрывается через физические, психологические, социально-культурные дескрипторы, которые характеризуют условия и ресурсы развития личности. Структурно-содержательные модели «среды жизнедеятельности человека», как правило, содержат пространственно-предметный и социальный компоненты: «физическая и жилищная организация пространства» и «отношения между людьми, среди которых растет ребенок». Анализируется «окружающая среда широкой поддержки» (среда сверстников, культурная, этническая, идеологическая, информационная, географическая). Среда развития ребенка включает «эмоциональную персональную среду», «социально-культурную среду», «технико-гигиеническую среду», «социально-экономическую» и «демографическую» среду. Рассматриваются семейная среда, «среда воспитательных и школьных учреждений» и «локальная среда» (микрорайон, поселок) (Черноушек, 1989). Методика анализа школьной среды «Шкала оценки условий ухода за школьниками» School-Age Care Environment Rating Scale (SACERS) включает такие содержательные разделы, как «внутреннее пространство и меблировка», «здоровье и безопасность», «активная деятельность», «взаимодействие», «учебная программа», «развитие персонала», «специальные нужды» (Harms et al., 1996). Популяризатор данной методики в России Е.В. Иванова отмечает: «Авторы SACERS провели заимствования из многих источников. Вместо того чтобы предлагать особую философию экспертной оценки, шкала SACERS основана на критериях адекватности образовательной среды возрастным особенностям детей и школьной программе» (Иванова Е.В., 2016, с. 7).

В целом анализ структурно-содержательных моделей среды развития личности и используемых параметров ее психологической дескрипции показывает методологическую целесообразность построения обобщенной системной структурно-содержательной модели среды (рисунок 1) и комплементарного такой модели комплекса характеризующих ее параметров.

\section{Психологические механизмы влияния среды на развитие личности}

Принципиальная важность понимания психологических механизмов влияния среды на развитие личности отражена в уже изложенной дискуссии 
Рисунок 1

Модель среды личностного развития, интегрирующая «экологический подход»

(У. Бронфенбреннер), модель «экологического комплекса» (О. Дункан и Л. Шноре), «средовой подход в воспитании» (Ю.С. Мануйлов), «теорию возможностей (Дж. Гибсон)

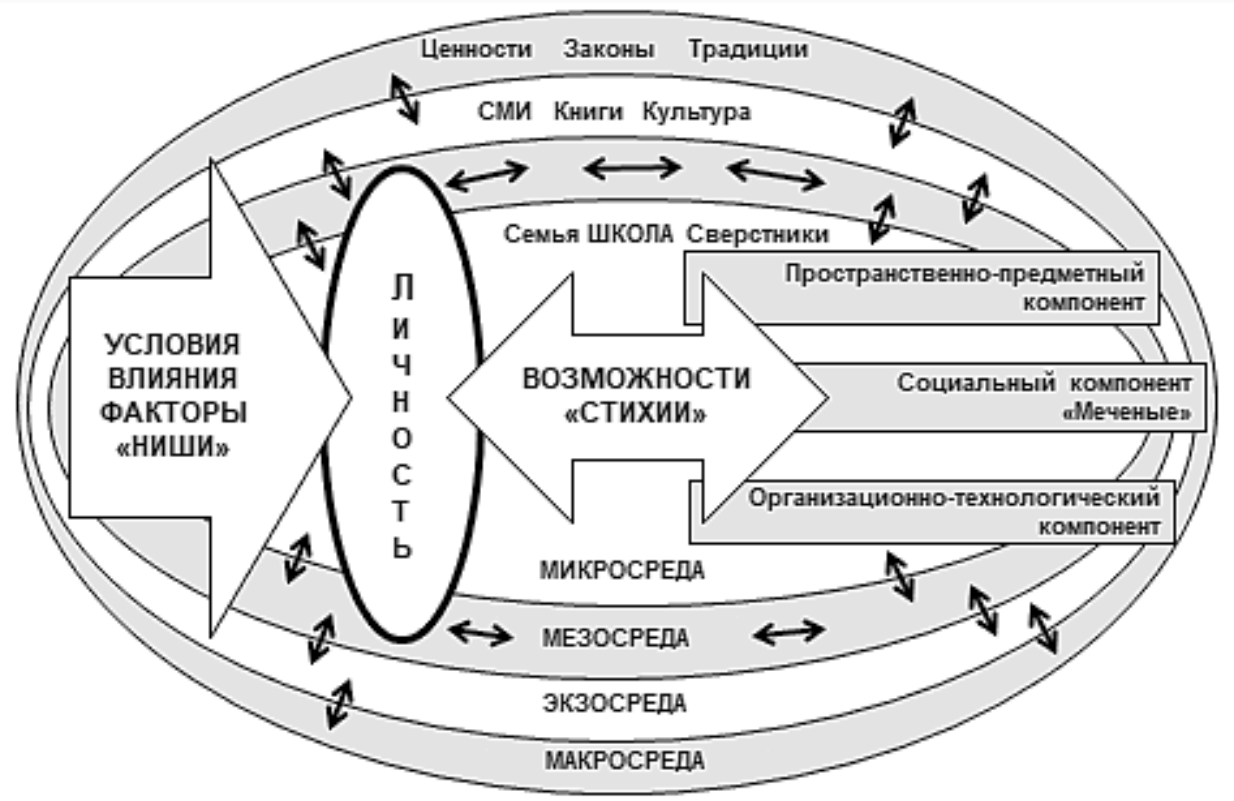

А.Н. Леонтьева и Л.С. Выготского. Более чем через полвека, анализируя психологические механизмы личностного развития, уже А.А. Леонтьев говорит о потребностях и возможностях развития личности в образовательной среде: «Понятие образовательной среды - одно из ключевых для образования психологических и педагогических понятий, только сейчас активно разрабатываемое. В этом контексте особенно важны выявленные психологами основные потребности и возможности развития, которые обеспечивает детям личностно ориентированная образовательная среда» (Леонтьев А.А., 2003, с. 50).

Психологические механизмы взаимодействия личности со средой раскрываются в теории возможностей Дж. Гибсона. Если в традиционных определениях среды используются такие понятия, как «условия», «влияния» и «факторы», то Дж. Гибсон, рассматривает «возможности» как «мост» между субъектом и средой. Возможности определяются как свойствами среды, так и свойствами самого субъекта в отличие от «условий», которые могут рассматриваться отдельно от субъекта.

Если «пространство» характеризуется условиями, то «среда» может быть охарактеризована через ее возможности. Можно сказать, что пространство становится средой, когда условия становятся возможностями. «Возможность» включает в себя как аспект переживания среды, акцентируемый Л.С. Выготским, так и проекцию предполагаемой деятельности, что было важно для А.Н. Леонтьева. 
Возможность связана с удовлетворением определенных потребностей людей, возбуждая их активность, что обеспечивает объединение ее средовых и личностных составляющих. Таким образом, качество образовательной среды зависит от богатства спектра возможностей для удовлетворения комплекса потребностей всех членов образовательного сообщества.

Наряду с популярной системой потребностей А. Маслоу (физиологических, в безопасности, любви, уважении, а также в самоактуализации) методологически перспективной представляется система «социогенных потребностей» Е.А. Климова: потребность усвоить мировоззренческие принципы, нормы морали, идеалы эталонной группы; потребности в определенных предметах питания, одежды, условиях быта (материальные потребности); потребность в признании со стороны общества (социальные потребности); потребность создать семью, воспитать детей; потребность в труде, общественно полезной деятельности; потребность сохранить или улучшить самооценку; потребность в познании специальной области явлений (интересы); потребность в преобразующей деятельности в какой-либо специальной области (склонности); потребность в эстетическом оформлении окружающей обстановки; потребность в самостоятельной выработке, упорядочении картины мира; потребность в овладении высоким уровнем мастерства в своем деле (Климов, 1997).

Педагогическое качество среды определяется ее способностью обеспечивать процесс онтогенетической трансформации источников мотивации ребенка от первичных потребностей в социогенные потребности - жизненные ценности. Процесс такой трансформации описан Д.А. Леонтьевым как движение от ценностей социальной среды (социальное внешнее) к личностным ценностям (социальное внутреннее) и социализации, движения от индивидуальных мотивов, основанных на потребностях (внутреннее биологическое), к ведущей роли ценностей (внутреннее социальное) (Леонтьев Д.А., 1996).

Таким образом, проектирование и организация личностно-развивающей среды (рисунок 2) - это, во-первых, создание в ней возможностей для удовлетворения всего иерархического комплекса потребностей и реализации ценностей всех членов образовательного сообщества. Во-вторых, проектирование и организация личностно-развивающей среды базируются на стремлении соответствовать критериям эффективной организации ее социального и пространственно-предметного компонентов.

Критерии эффективности социального компонента среды сформулированы в работах Н.П. Аникеевой, Л.И. Божович, Ю.Н. Емельянова, А.В. Запорожца, Е.С. Кузьмина, А.С. Макаренко, М.И. Лисиной, В.А. Сухомлинского и др.: 1) взаимопонимание и удовлетворенность взаимоотношениями; 2) преобладающее позитивное настроение; 3) авторитетность руководителей; 4) степень участия в управлении образовательным процессом; 5) сплоченность и сознательность; 6) продуктивность взаимодействий в обучающем компоненте образовательного процесса.

Критерии эффективности пространственно-предметного компонента среды сформулированы в работах Ю.Г. Абрамовой, В.В. Давыдова, Г.А. Ковалева, В.А. Петровского и др.: 1) гетерогенность и сложность среды; 2) связность 
Модель проектного поля личностно-развивающей среды

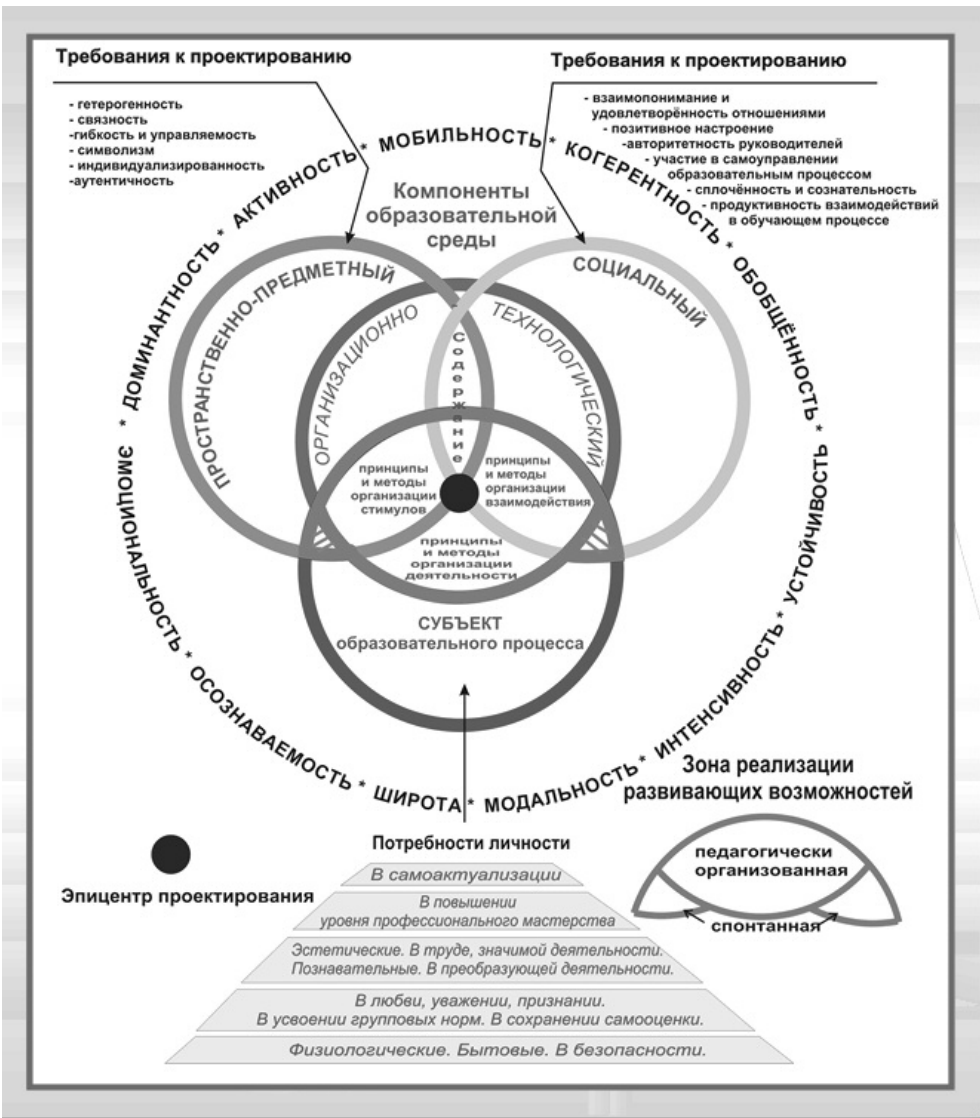

функциональных зон среды; 3) гибкость и управляемость среды; 4) обеспечение символической функции среды; 5) индивидуализированность среды; 6) аутентичность среды.

Наконец, в-третьих, качественная личностно-развивающая среда должна обладать высокими показателями ее системных количественных параметров: широты, интенсивности, осознаваемости, обобщенности, эмоциональности, доминантности, когерентности, социальной активности, структурированности, мобильности, безопасности и устойчивости.

\section{Методологические предпосылки становления обобщенной теории личностно-развивающей среды}

Сравнительный анализ различных методологических подходов к исследованию среды развития личности позволяет выделить ряд общих взаимодополняющих, не противоречащих друг другу позиций (Ясвин, 2018). 
1. В качестве агента взаимоотношений со средой рассматривается развивающаяся личность.

2. Образовательная среда рассматривается как специально организованное пространственно и/или событийно ограниченное окружение личности.

3. Среда понимается как совокупность условий, обстоятельств, событий, факторов и влияний на развивающуюся личность, а также развивающих личность возможностей, которым придается особое психолого-педагогическое значение.

4. Среда обладает ресурсным потенциалом личностного развития, который может быть реализован только путем активности самой личности.

5. Среда носит динамический характер.

6. В структуре среды выделяются пространственно-предметный, информационный, организационный, технологический и социальный компоненты. Социальному компоненту среды отводится наиболее значимая роль в формировании и развитии личности.

7. В определенном типе среды преимущественно формируется определенный тип личности.

8. Образовательная среда может быть описана через систему параметров, характеризующих различные аспекты ее организации и функционирования.

На основе теоретического анализа и синтеза различных средовых подходов нами сформулировано понятие «образовательная среда», которая понимается как пространственно и/или событийно ограниченная совокупность возможностей для развития личности, возникающих при ее взаимодействии со своим социальным и пространственно-предметным окружением.

Таким образом, выделенные теоретические положения, общие для различных средовых подходов в педагогике и педагогической психологии, сформулированное синтетическое определение понятия «образовательная среда», а также обобщенные структура и содержание дескрипторов среды представляются предпосылками для становления обобщенной теории среды развития личности в контексте формирования научного направления «экологическая психология образования» (Ясвин, 2013).

Проблематика исследований данного научного направления связана, прежде всего, со структурно-содержательным анализом образовательной среды; изучением средовых факторов развития личности; изучением психологических механизмов развития личности в образовательной среде; сравнительным анализом различных образовательных сред; гуманитарной экспертизой образовательных сред; типологией образовательных сред; изучением восприятия образовательной среды; изучением субъективных отношений к образовательной среде и в образовательной среде; проектированием инновационных образовательных сред; организацией эффективных образовательных сред.

Экологическая психология образования должна стать основой для создания экологической (средовой) педагогики, научного направления, обеспечивающего проектирование личностно-развивающих социальных и образовательных сред. Экологическая психология образования создает «психологическую матрицу» (процессы, механизмы, принципы, методы), на которую может 
быть наложена соответствующая педагогическая калька (технологии, приемы, методики). Например, на основе теоретических положений о зоне ближайшего развития Л.С. Выготского могут проектироваться «персональные среды ближайшего развития»; на основе метода векторного моделирования среды В.А. Ясвина может быть создана педагогическая технология управления модальностью образовательной среды учебного занятия и т.д.

Можно констатировать, что с начала XXI в., благодаря возрастающей популярности экологического подхода, наступает пятый эколого-психологический этап средовых исследований в педагогической психологии, следом за которым логично ожидать наступления шестого эколого-педагогического этапа.

\section{Литература}

Абрамова, Ю. Г. (1995). Особенности представлений учащихся о пространстве школьной среды (Кандидатская диссертация). Психологический институт РАО, Москва.

Артюхина, А. И. (2006). Образовательная среда высшего учебного заведения как педагогический феномен. Волгоград: ВолГМУ.

Богданов, Е. Н., Тюмасева, З. И. (2003). Образовательные системы и системное образование. Калуга: КГПУ им. К.Э. Циолковского.

Гибсон, Дж. (1988). Экологический подход к зрительному восприятию. М.: Прогресс.

Головлева, С. М. (2015). Компоненты образовательной среды субъектно-ориентированного типа педагогического процесса. Ярославский педагогический вестник, 4, 18-22.

Григорьева, М.В.(2010). Психологическая структура и динамика взаимодействий образовательной среды и ученика в процессе его школьной адаптации (Докторская диссертация). Саратовский государственный университет им. Н.Г. Чернышевского, Саратов.

Давыдов, В. В., Переверзев, Л. Б. (1976). К исследованию предметной среды для детей. Техническая эстетика, 2-3, 4-6.

Иванов, А. В. (2011). Педагогика среды: Учебное пособие для студентов высших педагогических учебных заведений. М.: АПКиППРО.

Иванов, А. В. (2016). Феномен культурной среды образовательной организации в освоении детьми духовных ценностей. Педагогческое образование в России, 3, 198-205.

Иванова, Е. В. (2016). Применение международной шкалы SACERS при экспертном оценивании условий реализации основной образовательной программы на ступенях начального и основного общего образования. Методист, 10, 5-8.

Иванова, Е. В., Нестерова, О. В., Виноградова, И. А. (2018). Исследование предметно-пространственной среды школы методом семантического дифференциала. Психолого-педагогические исследования, 1(10), 81-93.

Иванова, Н. В. (2016). Значимые параметры пространственно-предметного компонента образовательной среды для учащихся начальной школы. Общество: социология, психология, педагогика, 2, 84-88.

Исаева, Л. Б. (2012). Образовательная среда как предмет психолого-педагогических исследований. Вестник Казанского технологчческого университета, 13(15), 280-284.

Климов, Е. А. (1997). Основы психологии: Учебник для вузов. М.: Культура и спорт/ЮНИТИ.

Климов, Е. А. (2001). О среде обитания человека глазами психолога. В кн. 2-я Российская конференция по экологической психологии. Материаль (с. 7-9). М./Самара: Изд-во МГППИ. 
Корсакова, Т. В. (2010). Уклад школьной жизни: теоретическая модель. Известия Уральского государственного университета. Серия 1. Проблемь образования, науки и культуры, 6(85, ч. 2), 44-53.

Лактионова, Е. Б. (2013). Психологическая экспертиза образовательной среды (Докторская диссертация). РГПУ им. А.И. Герцена, Санкт-Петербург.

Лебедева, В. П., Орлов, В. А., Панов, В. И. (1996). Психодидактические аспекты развивающего образования. Педагогика, 6, 25-30.

Леонтьев, А. А. (2003). Принципы воспитания в Образовательной системе «Школа 2100». В кн. А. А. Леонтьев (ред.), Образовательная система «Школа 2100». Педагогика здравого смысла. Сборник материалов (с. 44-53). М.: «Баласс»/Издательский дом РАО.

Леонтьев, А. Н. (1998). Учение о среде в педологических работах Л.С. Выготского (критическое исследование). Вопросы психологии, 1, 108-127.

Леонтьев, Д. А. (1996). От социальных ценностей к личностным: социогенез и феноменология ценностной регуляции деятельности. Вестник Московского университета. Серия 14. Психология, 4, 35-44.

Лисицкая, В. П. (1996). Методы изучения среды в отечественной педагогике 20-30-х годов (Кандидатская диссертация). Владимирский педагогический университет, Владимир.

Мануйлов, Ю. С. (1997). Средовой подход в воспитании (Докторская диссертация). Университет Российской академии образования, Москва.

Нийт, Т., Хейдметс, М., Круусвал, Ю. (1985). Социально-психологические основы средообразования. Таллин.

Ожегов, С. И. (1986). Словарь русского языка. М.: Русский язык.

Панов, В. И. (2004). Экологическая психология: Опьт построения методологии. М.: Наука.

Петровский, В. А., Кларина, Л. М., Смывина, Л. А., Стрелкова, Л. П. (1993). Построение развивающей среды в дошкольном учреждении. М.: Научно-методическое объединение «Творческая педагогика»/«Новая школа».

Рубцов, В. В. (2001). О проблеме соотношения развивающих образовательных сред и формирования знания (к определению предмета экологической психологии). В кн. 2-я Российская конференция по экологической психологии. Материалы (с. 77-81). М./Самара: Изд-во МГППИ.

Савенков, А. И. (2006). Как рассадить детей в классе: психологическое пространство личности ребенка. М.: Чистые пруды.

Слободчиков, В. И. (2000). О понятии образовательной среды в концепции развивающего образования. В кн. 2-я Российская конференция по экологической психологии. Тезисы (с. 172-176). М.: Экопсицентр РОСС.

Смолова, Л. В. (2015). Психология взаимодействия с окружающей средой (экологическая психология). М.: ФЛИНТА.

Черноушек, М. (1989). Психология жизненной среды. М.: Мысль.

Ясвин, В. А. (1997). Моделирование образовательной среды. М.: ЦКФЛ РАО.

Ясвин, В. А. (2013). Экологическая психология образования как направление психолого-педагогической науки. Вестник Московского городского педагогического университета. Серия «Педагогика и психология», 26(4), 42-49.

Ясвин, В. А. (2018). Исследования образовательной среды в отечественной психологии: от методологических дискуссий к эмпирическим результатам. Известия Саратовского университета. Новая серия. Серия Философия. Психология. Педагогика, 18(1), 80-90.

Ссылки на зарубежные источники см. в разделе References после англоязычного блока. 
Ясвин Витольд Альбертович - профессор, департамент психологии, Институт педагогики и психологии образования, ГАОУ ВО «Московский городской педагогический университет», доктор психологических наук, профессор.

Сфера научных интересов: экологическая психология образования, экспертиза и проектирование образовательных систем, экологическое воспитание, социально-психологический тренинг.

Контакты: vitalber@yandex.ru 


\title{
Formation of the Theory of Environment of Personal Development in the Russian Pedagogical Psychology
}

\author{
W.A. Yasvin ${ }^{\mathrm{a}}$ \\ ${ }^{a}$ Moscow City University, 16 Stolyarny per., Moscow, 123022, Russian Federation
}

\begin{abstract}
Based on the analysis of publications, four stages of environmental studies of personal development in Russian psychology were identified: "pedological" - 1920s - beginning of 1930s; "culturalactivity" - the 1930s - 1960s; the "spatial" - 1970s; "personal-environmental" - since the mid 1990s; ecological and psychological - since the beginning of the XXI century; and ecological and pedagogical is being formed at the present time. A comparative analysis is conducted of the main methodological approaches, on the basis of which the study of educational environments in modern Russian pedagogical psychology and pedagogy is done: the collector's approach, spatial-objective approach, socio-psychological approach, environmental approach in education, cultural-historical approach and ecological approach. The possibility is proved for the generalized theory formation of environment for personality development on the basis of synthesis of key provisions of these approaches. The conceptual-terminological and structural-contensive voluntarism is revealed, which reduces the quality of research on the environment of personality development. The acquisition of developmental opportunities of the environment by the personality is considered as the main psychological mechanism of interaction of personality with environment and as the content of psychological design of the personal developmental environment. The concept of the educational environment was formulated and its structural and contensive model was designed that synthesizes the key provisions of different schools of thought. The educational environment is understood as a spatially and / or event-limited set of opportunities for personal development that arise in its interaction with its social and spatialobjective environment. A complex of systemic parameters for the description of environment is proposed, which meaningfully integrates various areas of research on environment of personality development: breadth, intensity, awareness, generality, emotionality, dominance, coherence, social activity, structure, mobility, security and stability. The emerging scientific direction of ecological psychology of education can become the basis for the creation of ecological pedagogy that provides the design for personal developmental social and educational environments. Ecological psychology of education creates a "psychological matrix" (processes, mechanisms, principles, methods), which can be overlaid with appropriate "pedagogical blueprint" (technologies, techniques, practices).
\end{abstract}

Keywords: environmental research in psychology, environment of personal development, educational environment, ecological psychology of education, conditions and opportunities of the environment.

\section{References}

Abramova, Yu. G. (1995). Osobennosti predstavlenii uchashchikhsya o prostranstve shkol'noi sredy [Specifics of students' notions of the space of school environment] (PhD dissertation). Institute of Psychology of the RAO, Moscow, Russian Federation. (in Russian) 
Artyukhina, A. I. (2006). Obrazovatel'naya sreda vysshego uchebnogo zavedeniya kak pedagogicheskii fenomen [Educational environment of the higher educational institution as a pedagogical phenomenon]. Volgograd: VolGMU. (in Russian)

Bogdanov, E. N., \& Tyumaseva, Z. I. (2003). Obrazovatel'nye sistemy i sistemnoe obrazovanie [Educational systems and systemic education]. Kaluga: KGPU im. K.E. Tsiolkovskogo. (in Russian)

Bronfenbrenner, U. (1979). The ecology of human development. Cambridge, MA: Harvard University Press.

Černoušek, M. (1989). Psikhologiya zhiznennoi sredy [The psychology of life environment]. Moscow: Mysl'. (in Russian)

Davydov, V. V., \& Pereverzev, L. B. (1976). K issledovaniyu predmetnoi sredy dlya detei [On the study of the object environment for children]. Tekhnicheskaya Estetika, 2-3, 4-6. (in Russian)

Duncan, O., \& Schnore, L. (1959). Cultural, behavioral and ecological perspectives in the study of social organization. American Journal of Sociology, 2(65), 132-153.

Gibson, J. (1988). Ekologicheskii podkhod k zritel'nomu vospriyatiyu [The ecological approach to visual perception]. Moscow: Progress. (in Russian; transl. of: Gibson, J. J. (1979). The ecological approach to visual perception. Boston, MA: Houghton Mifflin.)

Gibson, J. J. (1979). The ecological approach to visual perception. Boston, MA: Houghton Mifflin.

Golovliova, S. M. (2015). Educational environment components of the subject focused type of the pedagogical process. Yaroslavskii Pedagogicheskii Vestnik [Yaroslavl Pedagogical Bulletin], 4, 18-22. (in Russian)

Grigorieva, M. V. (2010). Psikhologicheskaya structura i dinamika vzaimodeistvii obrazovatel'noi sredy $i$ uchenika v protsesse ego shkol'noi adaptatsii [Psychological structure and dynamics of interaction between educational environment and student in the process of his school adaptation] (Doctoral dissertation). Saratov State University, Saratov, Russian Federation. (in Russian)

Harms, T., Jacobs, E., \& White, D. (1996). School-Age Care Environment Rating Scale. New York: Teachers College Press.

Isaeva, L. B. (2012). Obrazovatel'naya sreda kak predmet psikhologo-pedagogicheskikh issledovanii [Educational environment as a subject of psychological and pedagogical studies]. Vestnik Kazanskogo Tekhnologicheskogo Universiteta, 13(15), 280-284. (in Russian)

Ivanov, A. V. (2011). Pedagogika sredy [Pedagogy of environment]. Moscow: APKiPPRO. (in Russian) Ivanov, A. V. (2016). The role of cultural environment of educational organization in children's acquisition of spiritual values. Pedagogicheskoe Obrazovanie v Rossii [Pedagogical Education in Russia], 3, 198-205. (in Russian)

Ivanova, E. V. (2016). Primenenie mezhdunarodnoi shkaly SACERS pri ekspertnom otsenivanii uslovii realizatsii osnovnoi obrazovatel'noi programmy na stupenyakh nachal'nogo i osnovnogo obshchego obrazovaniya [Application of the international scale SACERS in the expert assessment of the conditions of realization of the main educational program at the levels of primary and secondary education]. Metodist, 10, 5-8. (in Russian)

Ivanova, E. V., Nesterova, O. V., \& Vinogradova, I. A. (2018). Physical parameters and comfort of the school environment in assessments of schoolchildren and teachers. Psychological-Educational Studies, 1(10), 81-93. (in Russian)

Ivanova, N. V. (2016). Significant parameters of space and object component of the educational environment for elementary school students. Obshchestvo: Sotsiologiya, Psikhologiya, Pedagogika [Society: Sociology, Psychology, Pedagogics], 2, 84-88. (in Russian) 
Klimov, E. A. (1997). Osnovy psikhologii [Foundations of psychology]. Moscow: Kul'tura i sport/YuNITI. (in Russian)

Klimov, E. A. (2001). O srede obitaniya cheloveka glazami psikhologa [On the habitat of humans from the point of view of psychologist]. In 2-ya Rossiiskaya konferentsiya po ekologicheskoi psikhologii. Materialy [The $2^{\text {nd }}$ Russian Conference on Ecological Psychology. Proceedings] (pp. 7-9). Moscow/Samara: MGPPI. (in Russian)

Korsakova, T. V. (2010). Uklad shkol'noi zhizni: teoreticheskaya model' [The school lifestyle: A theoretical model]. Izvestiya Ural'skogo Gosudarstvennogo Universiteta. Serie 1. Problemy Obrazovaniya, Nauki i Kul'tury, 6(85, pt. 2), 44-53. (in Russian)

Laktionova, E. B. (2013). Psikhologicheskaya ekspertiza obrazovatel'noi sredy [The psychological expertise of the educational environment] (Doctoral dissertation). Herzen State Pedagogical University of Russia, Saint Petersburg, Russian Federation. (in Russian)

Lebedeva, V. P., Orlov, V. A., \& Panov, V. I. (1996). Psikhodidakticheskie aspekty razvivayushchego obrazovaniya [Psychodidactic aspects of developmental education]. Pedagogika, 6, 25-30. (in Russian)

Leontiev, A. A. (2003). Printsipy vospitaniya v Obrazovatel'noi sisteme "Shkola 2100" [The principles of education in the Educational system "School 2100"]. In A. A. Leontiev (Ed.), Obrazovatel'naya sistema "Shkola 2100". Pedagogika zdravogo smysla. Sbornik materialov [Educational system "School 2100". The pedagogy of the common sense. Proceedings] (pp. 44-53). Moscow: Balass/RAO Publishing House. (in Russian)

Leontiev, A. N. (1998). The teaching on environment in pedological works of L.S. Vygotsky. Voprosy Psikhologii, 1, 108-127. (in Russian)

Leontiev, D. A. (1996). Ot sotsial'nykh tsennostei k lichnostnym: sotsiogenez i fenomenologiya tsennostnoi regulyatsii deyatel'nosti [From social to personal values: sociogenesis and phenomenology of value regulation of activity]. Vestnik Moskozskogo Universiteta. Serie 14. Psychology, 4, 35-44. (in Russian)

Lisitskaya, V. P. (1996). Metody izucheniya sredy v otechestvennoi pedagogike 20-30-kh godov [Methods to study environment in the national pedagogy] ( $\mathrm{PhD}$ dissertation). Vladimir State University, Vladimir, Russian Federation. (in Russian)

Manuilov, Yu. S. (1997). Sredovoi podkhod v vospitanii [Ecological approach in education] (Doctoral dissertation). Universitet Rossiiskoi akademii obrazovaniya, Moscow, Russian Federation. (in Russian)

McKown, C., \& Weinstein, R. S. (2008). Teacher expectations, classroom context, and the achievement gap. Journal of School Psychology, 46, 235-261.

Niit, T., Heidmets, M., \& Kruusval, Yu. (1985). Sotsial'no-psikhologicheskie osnovy sredoobrazovaniya [Social-psychological principles of ecological education]. Tallinn. (in Russian)

Ozhegov, S. I. (1986). Slovar' russkogo yazyka [A dictionary of Russian language]. Moscow: Russkii yazyk. (in Russian)

Panov, V. I. (2004). Ekologicheskaya psikhologiya: Opyt postroeniya metodologii [Ecological psychology: The experience of methodology building]. Moscow: Nauka. (in Russian)

Petrovsky, V. A., Klarina, L. M., Smyvina, L. A., \& Strelkova, L. P. (1993). Postroenie razvivayushchei sredy $v$ doshkol'nom uchrezhdenii [The formation of developmental environment in the pre-school]. Moscow: Nauchno-metodicheskoe ob"edinenie "Tvorcheskaya pedagogika"/Novaya shkola.

Rubtsov, V. V. (2001). O probleme sootnosheniya razvivayushchikh obrazovatel'nykh sred i formirovaniya znaniya ( $\mathrm{k}$ opredeleniyu predmeta ekologicheskoi psikhologii) [On the issue of correspondence of developmental educational environments and formation of knowledge (on the def- 
inition of the subject of ecological psychology)]. In 2-ya Rossiiskaya konferentsiya po ekologicheskoi psikhologii. Materialy [The $2^{\text {nd }}$ Russian Conference on Ecological Psychology. Proceedings] (pp. 77-81). Moscow/Samara: MGPPI. (in Russian)

Savenkov, A. I. (2006). Kak rassadit' detei v klasse: psikhologicheskoe prostranstvo lichnosti rebenka [How to seat children in the class: Psychological space of child's personality]. Moscow: Chistye prudy. (in Russian)

Slobodchikov, V. I. (2000). O ponyatii obrazovatel'noi sredy v kontseptsii razvivayushchego obrazovaniya [On the notion of educational environment in the concept of developmental education]. In 2-ya Rossiiskaya konferentsiya po ekologicheskoi psikhologii. Tezisy [The $2^{\text {nd }}$ Russian Conference on Ecological Psychology. Proceedings] (pp. 172-176). Moscow: Ekopsitsentr ROSS. (in Russian)

Smolova, L. V. (2015). Psikhologiya vzaimodeistviya s okruzhayushchei sredoi (ekologicheskaya psikhologiya) [Psychology of interaction with the environment (ecological psychology)]. Moscow: FLINTA. (in Russian)

Yasvin, V. A. (1997). Modelirovanie obrazovatel'noi sredy [Modeling of educational environment]. Moscow: TsKFL PAO. (in Russian)

Yasvin, V. A. (2013). Environmental psychology of education as a direction of psychological and pedagogical science. Vestnik Moskovskogo gorodskogo pedagogicheskogo universiteta. Seriya "Pedagogika i psikhologiya" [Vestnik of Moscow City University. Series "Pedagogy and Psychology"], 26(4), 42-49. (in Russian)

Yasvin, V. A. (2018). Research educational environment in Russian psychology: from methodological discussion by the empirical results. Izvestiya Saratovskogo universiteta. Novaya seriya. Seriya Filosofiya. Psikhologiya. Pedagogika [Izvestiya of Saratov University. New Series. Series: Philosophy. Psychology. Pedagogy], 18(1), 80-90. (in Russian)

Witold A. Yasvin - Professor, Department of psychology, Institute of pedagogy and psychology of education, Moscow City University, DSc in Psychology, Professor.

Research Area: environmental psychology of education, expertise and design of educational systems, environmental education, socio-psychological training.

E-mail: vitalber@yandex.ru 